Vol. 7 (1998): 409-422.

\title{
The effect of genotype on anther culture response of cultivated and wild oats
}

\author{
Elina Kiviharju, Matti Puolimatka \\ Agricultural Research Centre of Finland, Plant Production Research, Crops and Soil, \\ FIN-31600 Jokioinen, Finland, e-mail: elina.kiviharju@mtt.fi \\ Marketta Saastamoinen, Simo Hovinen \\ Boreal Plant Breeding, FIN-31600 Jokioinen, Finland \\ Eija Pehu \\ Department of Plant Production, PO Box 27, FIN-00014 University of Helsinki, Finland
}

\begin{abstract}
Anther culture ability was tested for 44 oat (Avena sativa $\mathrm{L}$.), six naked oat (A. sativa $\mathrm{L}$., naked type) and 15 wild oat (Avena sterilis L.) genotypes, in addition to progeny of five intraspecific crosses of A. sativa and two interspecific crosses of A. sativa $\times$ A. sterilis. Anther culture response was affected considerably by genotype. Thirty one oat genotypes responded by callus growth on induction medium and seven of them produced embryo structures, two of the lines consistently. All naked oat genotypes produced embryo structures. Embryo production rates for the wild oat lines were comparable with those for the naked oat genotypes, and higher than for oat: 13 of the 15 genotypes tested produced embryo structures. Plant regeneration was possible only from wild oat. The regeneration ability was inherited in the progeny of the A. sativa x A. sterilis cross cv. Puhti x CAV 2648 . The response of anthers of oat genotypes was inhibited by auxin on the induction medium, while naked oat, wild oat and A. sativa $\mathrm{x}$ A. sterilis crosses responded better on a medium containing 2,4-dichlorophenoxyacetic acid.
\end{abstract}

Key words: androgenesis, haploids, wild oat

\section{Introduction}

Production of doubled haploid (DH) lines using anther culture is useful in plant breeding for increasing the speed and efficiency of selection. It is also a tool for production of homozygous material for breeding and basic research purposes in many crop species, including cereals. New varieties have been developed via haploidy in wheat, Triticum aestivum L., (Hu et al. 1986, De Buyser et al. 1987, Pauk et al. 1995) barley, Hordeum vulgare L., (Kuhlmann and ForoughiWehr 1989, Ho and Jones 1980) and rice, Oryza sativa $\mathrm{L}$., (Croughan et al. 1985).

Cultivated oat (Avena sativa L.) has been shown to be a very recalcitrant cereal species regarding production of doubled haploids via 


\section{AGRICULTURAL AND FOOD SCIENCE IN FINLAND}

Kiviharju, E. et al. The effect of genotype on anther culture of oats

anther culture. To date the only report of successful anther culture of oat is by Rines (1983) who reported production of three anther-derived plants. Sun et al. (1991) recovered twelve green plants and one albino plant from anther culture of naked (hulless) oat. Recently, anther-derived plantlets were regenerated from wild oat, Avena sterilis L., however, at a low frequency (Kiviharju et al. 1997). Callus or embryoid induction from oat anther culture was reported also by Chung (1980) and Polsoni (1991), but no plants were regenerated.

Growth responses of cultured plant tissues are presumed to be under strong genetic control (Foroughi-Wehr et al. 1982, Bullock et al. 1982, Jones and Petolino 1987, Lazar et al. 1990, Hoffmann et al. 1991), and both callus initiation and haploid plant production were shown to be highly heritable traits in wheat and barley (Lazar et al. 1990). A strong genotypic effect on anther culture capacity was also reported in spring and winter wheat (Lazar et al. 1984, Tuvesson et al. 1989, Lu et al. 1991, Hoffman et al. 1991, Masojc et al. 1993, Orlov et al. 1993, Ghaemi and Sarrafi 1994), barley (Logue et al. 1993), maize, Zea mays L., (Petolino and Thompson 1987, Hongchang et al. 1991), rye, Secale cereale L. (Rakoczy-Trojanowska et al. 1997) and triticale, X Triticosecale Wittmack, (Balatero et al. 1995). It was also reported to be an important factor in anther culture of oat (Rines and McCoy 1980, Rines 1983, Rines et al. 1997), as well as in somatic embryogenesis from immature embryo explants (Rines and McCoy 1981, Gana et al. 1995).

The aim of this study was to investigate the genotype effect of cultivated oat on anther culture response in auxin-containing and hormonefree culture media. Different $A$. sterilis genotypes were also tested to establish whether this wild oat species has better responsiveness in anther culture (see Kiviharju et al. 1997). Furthermore, inheritance of anther culture ability and possible positive effect of heterozygosity were studied by culturing anthers of progenies of A. sativa x A. sativa and A. sativa $\times$ A. sterilis crosses.

\section{Material and methods}

\section{0at}

Forty four oat (A. sativa) genotypes (Table 1) were selected for testing. The genotypes were selected primarily from the Finnish oat gene pool and boreal vegetation zone. However, a few genotypes originating from other areas were also included. Donor plants were grown in the greenhouse under controlled conditions: $16^{\circ} \mathrm{C} / 12^{\circ} \mathrm{C}$ day/night temperatures, $16 \mathrm{~h}$ photoperiod. Light intensity supplemented by fluorescent lamps was $350 \mathrm{~mol} \mathrm{~m}^{-2} \mathrm{~s}^{-1}$. Seeds were sown in a peat soil $\operatorname{mix}(\emptyset 11 \mathrm{~cm}$ pots), two seeds per pot and fertilized with $1 \%$ solution of 5 -Superex ${ }^{\mathrm{TM}}$ Kekkilä, Finland; $11 \% \mathrm{~N}, 4 \% \mathrm{P}, 25 \% \mathrm{~K})$.

Culms were collected when the tip of the panicle inside the leaf sheath reached the level of the second leaf base. For cold pretreatment, excised culms were placed in conical flasks containing tap water at $+4^{\circ} \mathrm{C}$ in the dark for seven days. After the pretreatment the culms with panicles still enclosed in the leaf sheath were surface sterilized with $70 \%$ ethanol. Anthers containing late uninucleate stage microspores (Dunwell 1985) were isolated aseptically. The developmental stage of the microspores was determined using light-microscopy after squashing anthers in aceto-carmine. Because of the wide diversity of developmental stages of the anthers in one panicle of oat, the length and color of anthers was used as a morphological marker for selecting anthers containing microspores at the uninucleate stage. These characters were determined independently for each genotype.

Two induction media were used for anther culture: A-medium contained no growth regulators; B-medium was supplemented with $1.0 \mathrm{mg}$ $\mathrm{I}^{-1}$ 2,4-dichlorophenoxyacetic acid (2,4-D). Both media contained MS-salts and vitamins (Murashige and Skoog 1962), 10\% sucrose, and were adjusted to $\mathrm{pH}$ 5.8. Media were solidified with $0.3 \%$ Phytagel $^{\mathrm{TM}}$ (Sigma), and sterilized by autoclaving for $20 \mathrm{~min}$. at a temperature of $120^{\circ} \mathrm{C}$ and pressure of $1 \mathrm{~kg} \mathrm{~cm}^{-2}$. Isolated anthers $(60 /$ 
Vol. 7 (1998): 409-422.

Table 1. Anther culture response (callus and embryos) of different oat (Avena sativa) genotypes after eight week incubation on induction media without 2,4-D (A) and with $1 \mathrm{mg} \mathrm{l}^{-1}$ 2,4-D (B). ' number of anthers is equal to isolated anthers minus contaminated anthers.

\begin{tabular}{|c|c|c|c|c|c|c|c|c|c|c|c|}
\hline \multirow{2}{*}{\multicolumn{2}{|c|}{ genotype }} & \multicolumn{2}{|c|}{ no. of anthers ${ }^{1}$} & \multicolumn{2}{|c|}{$\begin{array}{l}\% \text { of anthers } \\
\text { responding }\end{array}$} & \multicolumn{2}{|c|}{$\begin{array}{l}\text { embryos/anthers } \\
\text { producing emb- } \\
\text { ryos, no./no. }\end{array}$} & \multicolumn{2}{|c|}{$\begin{array}{l}\% \text { of anthers } \\
\text { producing } \\
\text { embryos }\end{array}$} & \multicolumn{2}{|c|}{$\begin{array}{l}\text { embryo } \\
\text { structures } \\
/ 100 \text { anthers }\end{array}$} \\
\hline & & A & B & A & B & A & B & A & B & A & B \\
\hline \multicolumn{2}{|l|}{ Stout } & 600 & 300 & 10.5 & 5.0 & $8 / 8$ & $3 / 3$ & 1.3 & 1.0 & 1.3 & 1.0 \\
\hline \multicolumn{2}{|l|}{ Puhti } & 600 & 300 & 9.5 & 0.7 & 0 & 0 & 0 & 0 & 0 & 0 \\
\hline \multicolumn{2}{|l|}{ Sisko } & 600 & 300 & 0.3 & 0.3 & 0 & 0 & 0 & 0 & 0 & 0 \\
\hline \multicolumn{2}{|l|}{ Virma } & 600 & 540 & 0 & 0 & 0 & 0 & 0 & 0 & 0 & 0 \\
\hline \multicolumn{2}{|l|}{ Ryhti } & 600 & 300 & 2.2 & 0.7 & 0 & 0 & 0 & 0 & 0 & 0 \\
\hline \multicolumn{2}{|l|}{ Nasta } & 600 & 300 & 0 & 0 & 0 & 0 & 0 & 0 & 0 & 0 \\
\hline \multicolumn{2}{|l|}{ Sv 86432} & 600 & 300 & 0 & 0 & 0 & 0 & 0 & 0 & 0 & 0 \\
\hline \multicolumn{2}{|l|}{ Kolbu } & 600 & 300 & 1.2 & 0 & 0 & 0 & 0 & 0 & 0 & 0 \\
\hline \multicolumn{2}{|l|}{ WW 18019} & 600 & 300 & 2.2 & 1.0 & $14 / 7$ & $3 / 3$ & 1.2 & 1.0 & 2.3 & 1.0 \\
\hline \multicolumn{2}{|l|}{ Cascade } & 600 & 300 & 1.5 & 0.7 & $1 / 1$ & $2 / 2$ & 0.2 & 0.7 & 0.2 & 0.7 \\
\hline \multicolumn{2}{|c|}{ Heikki } & 600 & 300 & 7.7 & 3.0 & 0 & 0 & 0 & 0 & 0 & 0 \\
\hline \multicolumn{2}{|c|}{ Hankkijan Vouti } & 600 & 300 & 0.2 & 0 & 0 & 0 & 0 & 0 & 0 & 0 \\
\hline \multicolumn{2}{|c|}{ Yty } & 600 & 300 & 1.2 & 0 & $1 / 1$ & 0 & 0.2 & 0 & 0.2 & 0 \\
\hline Roope & & 600 & 300 & 0.5 & 0 & 0 & 0 & 0 & 0 & 0 & 0 \\
\hline Veli & & 600 & 300 & 0 & 0 & 0 & 0 & 0 & 0 & 0 & 0 \\
\hline Aarre & & 600 & 300 & 8.0 & 0.3 & 0 & 0 & 0 & 0 & 0 & 0 \\
\hline Freja & & 600 & 300 & 0 & 0 & 0 & 0 & 0 & 0 & 0 & 0 \\
\hline Pol & & 600 & 300 & 13.2 & 3.7 & 0 & 0 & 0 & 0 & 0 & 0 \\
\hline Park & & 600 & 300 & 0 & 0 & 0 & 0 & 0 & 0 & 0 & 0 \\
\hline Titus & & 600 & 300 & 0 & 0 & 0 & 0 & 0 & 0 & 0 & 0 \\
\hline Katri & & 600 & 300 & 0.5 & 0 & 0 & 0 & 0 & 0 & 0 & 0 \\
\hline ME 7539 & & 600 & 300 & 6.5 & 5.0 & 0 & 0 & 0 & 0 & 0 & 0 \\
\hline Alo & & 600 & 300 & 2.2 & 1.0 & 0 & 0 & 0 & 0 & 0 & 0 \\
\hline Sisu & & 600 & 300 & 4.2 & 2.0 & 0 & $1 / 1$ & 0 & 0.3 & 0 & 0.3 \\
\hline Pegaz & & 600 & 300 & 2.8 & 0.3 & 0 & 0 & 0 & 0 & 0 & 0 \\
\hline STH 180 & & 480 & 300 & 1.0 & 0.7 & 0 & 0 & 0 & 0 & 0 & 0 \\
\hline Wiesel & & 600 & 300 & 0 & 0.3 & 0 & 0 & 0 & 0 & 0 & 0 \\
\hline Maldwyn & & 540 & 300 & 0.4 & 0.3 & 0 & 0 & 0 & 0 & 0 & 0 \\
\hline Myriane & & 600 & 300 & 3.8 & 0 & 0 & 0 & 0 & 0 & 0 & 0 \\
\hline Avesta & & 600 & 300 & 0 & 0.3 & 0 & 0 & 0 & 0 & 0 & 0 \\
\hline Ogle & & 600 & 300 & 0 & 0 & 0 & 0 & 0 & 0 & 0 & 0 \\
\hline Ceal & & 360 & 300 & 10.8 & 2.7 & 0 & 0 & 0 & 0 & 0 & 0 \\
\hline OT257 & & 480 & 300 & 0.2 & 0.3 & 0 & $1 / 1$ & 0 & 0.3 & 0 & 0.3 \\
\hline Talgai & & 600 & 300 & 0.2 & 0 & $1 / 1$ & 0 & 0.2 & 0 & 0.2 & 0 \\
\hline Semu 4.004 & & 600 & 300 & 0 & 0 & 0 & 0 & 0 & 0 & 0 & 0 \\
\hline Fuchs & & 420 & 300 & 0 & 0 & 0 & 0 & 0 & 0 & 0 & 0 \\
\hline Hјa 86008 & & 600 & 300 & 0.7 & 1.0 & 0 & 0 & 0 & 0 & 0 & 0 \\
\hline Hja 85013 & & 600 & 300 & 0 & 0.3 & 0 & 0 & 0 & 0 & 0 & 0 \\
\hline Mostyn & & 480 & 240 & 0 & 0 & 0 & 0 & 0 & 0 & 0 & 0 \\
\hline Salo & & 420 & 300 & 0 & 0 & 0 & 0 & 0 & 0 & 0 & 0 \\
\hline Amby & & 240 & 180 & 0 & 0 & 0 & 0 & 0 & 0 & 0 & 0 \\
\hline STH 7518 & & 240 & 180 & 0 & 0 & 0 & 0 & 0 & 0 & 0 & 0 \\
\hline Ebene & & 300 & 300 & 0.3 & 0 & 0 & 0 & 0 & 0 & 0 & 0 \\
\hline Rollo & & 300 & 240 & 0.3 & 0 & 0 & 0 & 0 & 0 & 0 & 0 \\
\hline all & $\begin{array}{l}\bar{x} \\
s . d .\end{array}$ & & & $\begin{array}{l}2.09 \\
3.50\end{array}$ & $\begin{array}{l}0.67 \\
1.27\end{array}$ & & & & & & \\
\hline responding & $\overline{\mathrm{x}}$ & & & 3.41 & 1.41 & & & & & 0.84 & 0.66 \\
\hline & s.d. & & & 3.95 & 1.55 & & & & & 0.94 & 0.35 \\
\hline
\end{tabular}




\section{AGRICULTURAL AND FOOD SCIENCE IN FINLAND}

Kiviharju, E. et al. The effect of genotype on anther culture of oats

dish) were placed in Petri dishes $(\varnothing 6 \mathrm{~cm}$, Greiner) containing $10 \mathrm{ml}$ of culture medium. In total, 600 anthers of each genotype were cultured on A-medium and 300 anthers on B-medium. Dishes were incubated at $+25^{\circ} \mathrm{C}$ in the dark and anther response was assessed after eight weeks. The experiment was repeated with eight genotypes which produced embryo structures. As the carbohydrate source, $10 \%$ sucrose or $10 \%$ maltose was used in filter-sterilized A-medium (4 ml medium in $3.5 \mathrm{~cm} \varnothing$ Petri dishes, Falcon). Three hundred anthers were cultured per genotype (30 anthers/dish). In total, $13 \mathrm{MS}$ or $\mathrm{N}_{6}$ based differentiation media were used containing various concentrations of auxins (2,4-D, 1-naphthaleneacetic acid (NAA), indoleacetic acid (IAA)) and/or cytokinins (kinetin, 6-benzylaminopurine (BAP), zeatin), carbohydrates (maltose or sucrose, 2-10\%), glutamine, myoinositol and in some cases activated charcoal.

\section{Naked oat, wild oat and crosses}

Six naked oat (A. sativa L., naked type) genotypes and 15 wild oat (A. sterilis) genotypes were included in this study. Seeds of F-2 progeny of five different oat (A. sativa $\times$ A. sativa) crossings and two different oat $\mathrm{x}$ wild oat (A. sativa $\mathrm{x}$ A. sterilis) crossings were sown to produce the anther-donor plants. Genotypes are given in Table 2 .

Donor plant growing conditions were similar to those for oat, except that $14 \mathrm{~cm}$ diameter pots were used and three seeds sown in each. Two induction media were used: A-medium contained no growth regulators; B-medium was supplemented with $5.0 \mathrm{mg} \mathrm{l}^{-1}$ 2,4-D. Both media contained MS-salts and vitamins, $10 \%$ maltose, and were adjusted to $\mathrm{pH}$ 5.8. The media were layered in solid and liquid phases: the lower layer was solidified with $0.3 \%$ Phytagel $^{\mathrm{TM}}$ (Sigma), the upper liquid layer contained $10 \%(w / v)$ Ficoll 400. The solid layer was filter-sterilized (Phytagel $^{\mathrm{TM}}$ was autoclaved in a small amount of water) and the liquid part autoclaved (20 min at $120^{\circ} \mathrm{C}$ and pressure of $1 \mathrm{~kg} \mathrm{~cm}^{-2}$ ). After cold pretreatment at $+4^{\circ} \mathrm{C}$ for seven days, naked oat and wild oat culms were sterilized as above, whereas panicles of crosses were removed from the leaf sheaths and sterilized in $2.0 \% \mathrm{NaOCl}$ solution for $20 \mathrm{~min}$ and rinsed five times with sterilized water. Isolated anthers (30/dish) were placed in Petri dishes (Ø $35 \mathrm{~mm}$, Falcon) containing $2.5 \mathrm{ml}$ of solid culture medium and 1.0 $\mathrm{mg} \mathrm{l}^{-1}$ liquid medium. The uninucleate state of microspores was determined as in the A. sativa experiments. In total, 150-450 anthers were cultured per genotype per medium depending on the number of seeds available. Plated anthers were pretreated at $+32^{\circ} \mathrm{C}$ for five days before incubation at $+25^{\circ} \mathrm{C}$ in the dark. Anther culture response was assessed after eight weeks. Embryo structures were transferred onto solidified, filter-sterilized differentiation medium E-31 containing MS salts and vitamins, $1.0 \mathrm{mg} \mathrm{l}^{-1}$ kinetin, $4 \%$ maltose and $0.3 \%$ Phytagel $^{\mathrm{TM}}$ at $\mathrm{pH} 5.8$. For naked oat embryos, E-65 differentiation medium (E-31 supplemented with $0.2 \mathrm{mg} \mathrm{l}^{-1} \mathrm{NAA}$ ) was also used. Regenerated plantlets were transferred onto filter-sterilized, or autoclaved, rooting medium containing MS salts and vitamins, $3 \%$ sucrose, $0.3 \%$ Phytagel $^{\mathrm{TM}}$ and no growth regulators at $\mathrm{pH} 5.8$.

Ploidy level of regenerants was determined by flow cytometry analysis (FACSort, Becton Dickinson) of propidium iodide stained nuclei isolated from leaf tissue. The barley cultivar 'Sultan' was used as the control $(4 \mathrm{C}=22.24 \mathrm{pg}$ DNA; Michaelson et al. 1991, Bennett et al. 1982).

\section{Results}

\section{Oat}

Response of anthers of different genotypes fell into two categories: callus production and direct embryogenesis (Kiviharju et al. 1997). Thirty of 


\section{AGRICULTURAL AND FOOD SCIENCE IN FINLAND}

Vol. 7 (1998): 409-422.

Table 2. Anther culture response of wild oat (Avena sterilis), naked oat (A. sativa, naked type), A. sativa $\mathrm{x}$ A. sativa and A. sativa $\times$ A. sterilis crosses after eight weeks on hormone-free $(\mathrm{A})$ and $5 \mathrm{mg} \mathrm{l}^{-1}$ 2,4-D $(\mathrm{B})$ containing induction media. gh $=$ greenhouse, transferred $=$ transferred onto differentiation media. ${ }^{1}$ number of anthers is equal to isolated anthers minus contaminated anthers.

\begin{tabular}{|c|c|c|c|c|c|c|c|c|c|c|c|c|c|}
\hline \multirow{2}{*}{\multicolumn{2}{|c|}{ genotype }} & \multicolumn{2}{|c|}{ no. of anthers ${ }^{1}$} & \multicolumn{2}{|c|}{$\begin{array}{l}\text { embryos } \\
/ 100 \text { anthers }\end{array}$} & \multicolumn{2}{|c|}{$\begin{array}{l}\text { transferred } \\
\text { embryos } \\
/ 100 \text { anthers }\end{array}$} & \multicolumn{2}{|c|}{$\begin{array}{l}\text { regenerants } \\
/ 100 \text { anthers } \\
\text { green }\end{array}$} & \multicolumn{2}{|l|}{ albino } & \multicolumn{2}{|c|}{$\begin{array}{l}\text { plants in gh } \\
/ 100 \text { anthers }\end{array}$} \\
\hline & & A & B & A & B & A & B & A & B & A & B & A & B \\
\hline \multicolumn{14}{|l|}{ wild oat: } \\
\hline \multicolumn{2}{|l|}{ CAV 1126} & 420 & 360 & 0 & 13.9 & 0 & 0.8 & 0 & 0 & 0 & 0 & 0 & 0 \\
\hline \multicolumn{2}{|l|}{16} & 300 & 420 & 5.6 & 54.3 & 2.7 & 25.0 & 0 & 2.6 & 0.3 & 0.2 & 0 & 2.6 \\
\hline \multicolumn{2}{|l|}{$3 \mathrm{a}$} & 300 & 300 & 1.0 & 1.0 & 0 & 0.3 & 0 & 0 & 0 & 0 & 0 & 0 \\
\hline \multicolumn{2}{|l|}{ CW 537} & 150 & - & 0 & - & 0 & - & 0 & 0 & 0 & 0 & 0 & 0 \\
\hline \multicolumn{2}{|l|}{ Ciav 2321} & 450 & 450 & 0 & 0.7 & 0 & 0 & 0 & 0 & 0 & 0 & 0 & 0 \\
\hline \multicolumn{2}{|l|}{55} & 360 & 270 & 1.7 & 33.3 & 1.7 & 9.2 & 0 & 0 & 0 & 0 & 0 & 0 \\
\hline \multicolumn{2}{|l|}{ CW 533} & 300 & 300 & 111.7 & 189.0 & 67.7 & 98.3 & 1.3 & 13.3 & 0 & 0.3 & 1.3 & 12.3 \\
\hline \multicolumn{2}{|l|}{ CW 453} & 300 & 300 & 0.3 & 4.3 & 0 & 0.7 & 0 & 0 & 0 & 0 & 0 & 0 \\
\hline \multicolumn{2}{|l|}{ CAV 1095} & 300 & 300 & 0 & 0 & 0 & 0 & 0 & 0 & 0 & 0 & 0 & 0 \\
\hline \multicolumn{2}{|l|}{ CD 7983} & 300 & 270 & 1.0 & 5.5 & 0.3 & 4.1 & 0 & 0 & 0 & 0 & 0 & 0 \\
\hline CAV 1191 & & 300 & 300 & 0.3 & 17.3 & 0 & 2.7 & 0 & 0.3 & 0 & 0.3 & 0 & 0.3 \\
\hline CAV 2941 & & 300 & 300 & 4.7 & 116.7 & 4.7 & 70.0 & 0.3 & 2.0 & 0 & 0.3 & 0 & 2.0 \\
\hline CAV 3175 & & 300 & 300 & 10.7 & 11.7 & 0 & 1.0 & 0 & 0 & 0 & 0 & 0 & 0 \\
\hline WAHL 6 & & 300 & 300 & 1.0 & 2.7 & 0 & 0 & 0 & 0 & 0 & 0 & 0 & 0 \\
\hline CAV 2057 & & 300 & 270 & 1.1 & 0 & 0 & 0 & 0 & 0 & 0 & 0 & 0 & 0 \\
\hline all & $\overline{\mathrm{x}}$ & & & 9.27 & 32.17 & 5.14 & 15.15 & & & & & & \\
\hline & s.d. & & & 28.49 & 55.18 & 17.36 & 30.49 & & & & & & \\
\hline responding & $\bar{x}$ & & & 12.65 & 37.53 & 15.42 & 21.21 & & & & & & \\
\hline & s.d. & & & 33.00 & 58.14 & 29.27 & 34.64 & & & & & & \\
\hline naked oat: & & & & & & & & & & & & & \\
\hline Lisbeth & & 450 & 450 & 0 & 0.4 & 0 & 0 & 0 & 0 & 0 & 0 & 0 & 0 \\
\hline Jo 1418 & & 450 & 450 & 3.1 & 13.6 & 0.9 & 13.6 & 0 & 0 & 0 & 0 & 0 & 0 \\
\hline Jo 1419 & & 450 & 450 & 0.4 & 2.7 & 0.2 & 2.7 & 0 & 0 & 0 & 0 & 0 & 0 \\
\hline Bor 1335 & & 450 & 450 & 0 & 0.7 & 0 & 0.2 & 0 & 0 & 0 & 0 & 0 & 0 \\
\hline Bor 1267 & & 450 & 450 & 0.4 & 2.7 & 0.2 & 0.9 & 0 & 0 & 0 & 0 & 0 & 0 \\
\hline Bor 1306 & & 390 & 390 & 13.1 & 169.2 & 2.1 & 79.5 & 0 & 0 & 0 & 0 & 0 & 0 \\
\hline all & $\overline{\mathrm{x}}$ & & & 2.83 & 31.55 & 0.57 & 16.15 & & & & & & \\
\hline & s.d. & & & 5.16 & 67.61 & 0.82 & 31.46 & & & & & & \\
\hline responding & $\bar{x}$ & & & 4.25 & & 0.85 & 19.38 & & & & & & \\
\hline & s.d. & & & 6.04 & & 0.90 & 34.04 & & & & & & \\
\hline A. sativa $\mathrm{x}$ & A. sativa. & & & & & & & & & & & & \\
\hline Fuchs $\times$ PC & 62 & 300 & 150 & 0 & 0.7 & 0 & 0 & 0 & 0 & 0 & 0 & 0 & 0 \\
\hline Bor $70623 \times$ & Bor 70818 & 450 & 300 & 0 & 1.0 & 0 & 0 & 0 & 0 & 0 & 0 & 0 & 0 \\
\hline Нja 88612 x & Bor 70584 & 300 & 210 & 0 & 2.5 & 0 & 1.3 & 0 & 0 & 0 & 0 & 0 & 0 \\
\hline NS $126-93 \times 1$ & Il $86-4189$ & 270 & 240 & 1.9 & 13.3 & 0 & 4.2 & 0 & 0 & 0 & 0 & 0 & 0 \\
\hline Hja $87712 x$ & APR 166 & 450 & 300 & 3.8 & 4.0 & 3.1 & 0.7 & 0 & 0 & 0 & 0 & 0 & 0 \\
\hline all & $\overline{\mathrm{x}}$ & & & 1.14 & 4.30 & 0.62 & 1.24 & & & & & & \\
\hline & s.d. & & & 1.70 & 5.20 & 1.39 & 1.74 & & & & & & \\
\hline responding & $\overline{\mathrm{x}}$ & & & 2.85 & 4.30 & 3.1 & 2.07 & & & & & & \\
\hline & s.d. & & & 1.34 & 5.20 & 0 & 1.87 & & & & & & \\
\hline A. sativa $\mathrm{x}$ & A. sterilis & & & & & & & & & & & & \\
\hline Puhti $x$ CA & V 2648 & 450 & 390 & 23.1 & 67.9 & 11.6 & 31.4 & 0.2 & 0.5 & 0 & 0.5 & 0.2 & 0.2 \\
\hline KP $9304 \times C$ & CAV 2648 & 300 & 150 & 15.7 & 138.7 & 0.3 & 50.0 & 0 & 0 & 0 & 0 & 0 & 0 \\
\hline all & $\bar{x}$ & & & 19.40 & 103.30 & 5.95 & 40.70 & & & & & & \\
\hline & s.d. & & & 5.23 & 50.06 & 7.99 & 13.15 & & & & & & \\
\hline
\end{tabular}




\section{AGRICULTURAL AND FOOD SCIENCE IN FINLAND}

Kiviharju, E. et al. The effect of genotype on anther culture of oats

the 44 oat genotypes included in the study produced callus on either of the induction media (Table 1). Callus induction among different varieties ranged from 0 to $13.2 \%$ on hormone-free medium $(\bar{x}=2.1$, s.d. $=3.50)$ and 0 to $5.0 \%$ on 2,4-D containing medium $(\overline{\mathrm{x}}=0.7$, s.d. $=1.27)$. Over 5\% induction was achieved in 'Puhti' (13.5\%), 'Pol' (13.2\%), 'Ceal' (10.8\%), 'Stout' $(10 \%)$, 'Aarre' (8\%), 'Heikki' (7.7\%) and line ME $7539(6.5 \%)$ on hormone-free medium. Fourteen genotypes did not respond on the induction medium. Seven of the genotypes produced callus only on medium without $2,4-\mathrm{D}$, while three genotypes produced callus only on medium with 2,4-D. Mean callus induction percentage over all genotypes cultured on 2,4-D containing medium was only $32 \%$ of the mean of the induction percentage on hormone-free medium.

Seven genotypes of oat produced microsporederived embryo structures (WW 18019, Stout, 'Cascade', 'Sisu', 'OT257', 'Yty' and 'Talgai') (Table 1, Fig. 1a). WW 18019 and Stout showed markedly higher responses than the other five genotypes. In WW $180191.2 \%$ of the anthers produced embryos (2.3 embryos/100 anthers) and in Stout $1.3 \%$ of the anthers produced embryos (1.3 embryos/100 anthers). When the experiment was repeated with these seven genotypes, only WW 18019 and Stout produced embryo structures. Maltose was shown to be a better carbon source than sucrose as WW 18019 and Stout produced 4.3 and 2.7 embryos/100 anthers respectively on the maltose containing medium, while only WW 18019 produced embryos ( 0.7 embryos/100 anthers) on sucrose-containing medium. As for callus induction, the best embryo production rate was obtained on medium without 2,4-D (WW 180192.3 embryo structures/100 anthers); four genotypes produced more embryos on hormone-free medium, three on 2,4-D containing medium, but in general embryo induction rates were very low. No plants were regenerated.

\section{Naked oat}

In contrast to the results for oat, naked oat, wild oat and progeny of the interspecific crosses differentiated directly into embryo structures and no callus initiation was observed. The six genotypes tested produced embryo structures, two of them only on 2,4-D containing medium (Table $2)$. Higher induction rates were achieved on medium containing 2,4-D compared with hormone-free medium, but the variation between the genotypes was high (in medium $\mathrm{A}, \overline{\mathrm{x}}=2.8$, s.d. $=5.16$; in medium $\mathrm{B}, \overline{\mathrm{x}}=31.55$, s.d. $=67.61$ ). Line Bor 1306 produced up to 169.2 embryos/ 100 anthers, of which 79.5 embryos/100 anthers reached adequate size to be transferred onto differentiation media. The second best line, Jo 1418, produced only 13.6 embryos/100 anthers, all of which were transferred onto differentiation media.

\section{Wild oat}

Thirteen of the 15 lines tested produced embryo structures (Table 2, Fig. 1b). There was great variation in anther culture ability between the lines. Embryo induction varied between 0 and 111.7 embryos/100 cultured anthers on hormonefree medium $(\bar{x}=9.3$ embryos $/ 100$ anthers, s.d. $=28.5$ ), and 0 to 189.0 on 2,4-D containing me$\operatorname{dium}(\overline{\mathrm{x}}=32.2$ embryos $/ 100$ anthers, $\mathrm{s} . \mathrm{d} .=55.2)$. As for naked oat genotypes, embryo induction was generally higher on medium containing 2,4$\mathrm{D}$, although one line produced embryos only on hormone-free medium (CAV 2057). Ten genotypes produced embryos, which reached the size when they could be transferred onto the differentiation medium. Three genotypes produced 25 or more embryos/100 cultured anthers of transferrable size during eight weeks of culture: CW 533 (67.7 on A-medium; 98.3 on B-medium), CAV 2941 (70.0 on B-medium) and 16 (25.0 on B-medium). 


\section{AGRICULTURAL AND FOOD SCIENCE IN FINLAND}

Vol. 7 (1998): 409-422.

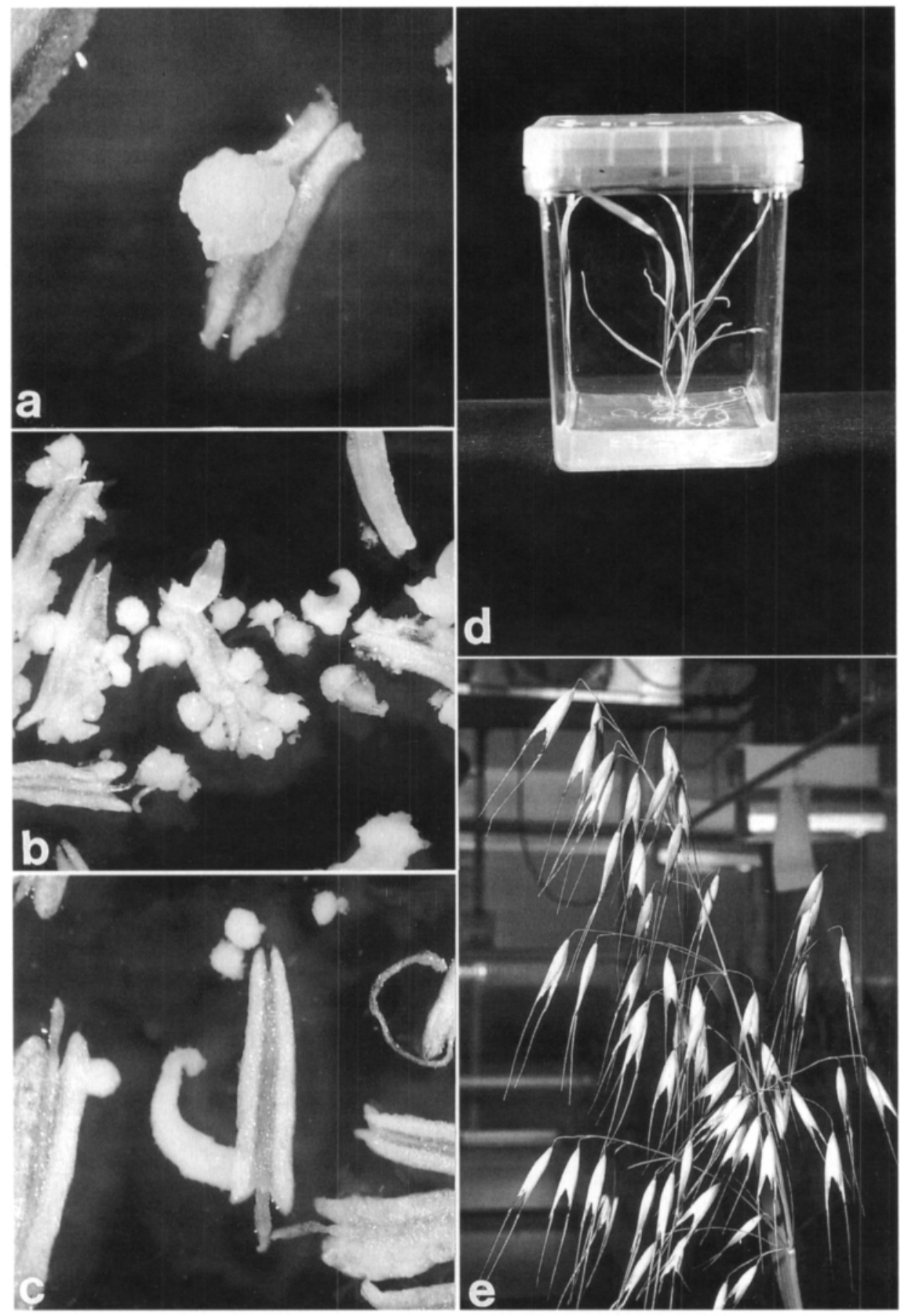

Fig. 1. a) An embryo structure developed from an anther of oat Avena sativa cv. Sisu on an induction medium containing auxin. b) Embryo structures initiated from anthers of wild oat Avena sterilis line CAV 2941 on an induction medium containing auxin. c) Embryo structure developing from an anther of A. sativa x A. sterilis cross Puhti x CAV 2648 on an induction medium containing auxin. d) Regenerated plantlet of A. sativa x A. sterilis cross Puhti x CAV 2648 on rooting medium. e) Panicle of non-fertile, haploid, mature plant from A. sativa x A. sterilis cross Puhti x CAV 2648. 


\section{AGRICULTURAL AND FOOD SCIENCE IN FINLAND}

\section{Kiviharju, E. et al. The effect of genotype on anther culture of oats}

Four lines, 16, CW 533, CAV 1191 and CAV 2941, produced green plants. Most of the plants were regenerated from embryos produced on 2,4D containing medium. In total, 41 green plants of the most responsive line, CW 533, (600 anthers cultured) survived in the greenhouse. Four of the plants ( 1.3 plants/100 anthers) were induced on hormone-free medium and 37 (12.3 plants/100 anthers) on 2,4-D containing medium. Few albinos were produced, most originating from 2,4-D containing medium. Approximately two thirds of the plants of the two best responsing lines (CW 533 and 16) regenerated from embryos induced on B-medium were haploids $(n=3 x=21)$ (Table 3, Fig. 2c). In addition to haploids and diploids $(2 \mathrm{n}=6 \mathrm{x}=42)$ (Fig. $2 \mathrm{~b})$, $8 \%$ of the plants regenerated from the line CW 533 had chromosome numbers of higher ploidy levels (9x, 12x) (Fig. 2d). Of the plants regenerated on hormone-free medium one plant was haploid, two were diploids and one of a higher ploidy level (Fig. 2). Lines CAV 2941 and CAV 1191 regenerated only haploid plants.

\section{Crosses}

The best embryo induction from the A. sativa $\mathrm{x}$ A. sativa crosses (13.3 embryos/100 anthers) was achieved for the cross NS 126-93 x Il 86-4189 on 2,4-D containing medium (Table 2). 4.2 em- bryos/100 anthers were transferred onto differentiation media. For all of the progenies, 2,4-D containing medium gave better results $(\bar{x}=4.3$ embryos $/ 100$ anthers, s.d. $=5.2$ ) than hormonefree medium $(\bar{x}=1.1$, s.d. $=1.7)$. Three of the five crosses showed no response on medium without 2,4-D. No plants regenerated from embryos transferred onto differentiation media (in total 29 embryos were transferred from the three crosses).

Embryo induction rates for the two A. sativa $\mathrm{x}$ A. sterilis crosses tested were markedly higher than embryo induction rates for A. sativa $\mathrm{x} A$. sativa crosses (Table 2, Fig. 1c). Embryo induction was 3 to 8 times higher on 2,4-D containing medium $(\bar{x}=103.3$, s.d. $=50.1)$ than on hormonefree medium $(\overline{\mathrm{x}}=19.4$, s.d. $=5.2)$. KP $9304 \mathrm{x}$ CAV 2648 produced 138.7 embryos/100 anthers on 2,4-D containing medium, of which $50 \mathrm{em}$ bryos/100 anthers were transferred onto differentiation medium. No plant regeneration was achieved for this cross. Although Puhti x CAV 2648 gave lower embryo induction results $(67.9$ embryos/100 anthers, of which 31.4 transferred embryos/100 anthers on B-medium), three green plants and two albinos were regenerated (Fig. $1 d, 1 e)$. One diploid $(2 n=6 x=42)$ green plant regenerated on the hormone-free medium, and the other two green plants (one haploid $(n=3 x=21)$, the other one died before transfer into greenhouse) and the two albino plants on auxin-containing medium.

Table 3. Ploidy level of green plants of Avena sterilis and Avena sativa x A. sterilis crosses produced by anther culture. $\mathrm{A}=$ hormone-free, $\mathrm{B}=5 \mathrm{mg} \mathrm{l}^{-1} 2,4-\mathrm{D}, \mathrm{gh}=$ greenhouse, " no seed set

\begin{tabular}{llllllll}
\hline Genotype & $\begin{array}{l}\text { plants } \\
\text { in gh } \\
\text { no. }\end{array}$ & $\begin{array}{l}\text { induction } \\
\text { medium } \\
\text { no. }(\%)\end{array}$ & $\begin{array}{l}\text { haploid } \\
(\mathrm{n}=3 \mathrm{x}=21) \\
\text { no. }(\%)\end{array}$ & $\begin{array}{l}\text { diploid } \\
(2 \mathrm{n}=6 \mathrm{x}=42) \\
\text { no. }(\%)\end{array}$ & $\begin{array}{l}\text { higher ploidy } \\
(2 \mathrm{n}=9 \mathrm{x}, 12 \mathrm{x}) \\
\text { no. }(\%)\end{array}$ & $\begin{array}{l}\text { dead } \\
\text { in gh } \\
\text { no. }\end{array}$ & $\begin{array}{l}\text { not } \\
\text { analyzed } \\
\text { no. }(\%)\end{array}$ \\
\hline 16 & 11 & B & $7(64)$ & $4(36)$ & 0 & 0 & \\
CW 533 & 4 & A & $1(25)$ & $2(50)$ & $1(25)$ & 0 & 1 \\
CW 533 & 37 & B & $24(65)$ & $9(24)$ & $3(8)$ & 0 & $1(3)$ a \\
CAV 2941 & 6 & B & $6(100)$ & 0 & 0 & 0 & 0 \\
CAV 1191 & 1 & B & $1(100)$ & 0 & 0 & 0 & \\
Puhti x CAV 2648 & 1 & A & 0 & $1(100)$ & 0 & 0 & 0 \\
Puhti x CAV 2648 & 1 & B & $1(100)$ & 0 & 0 & \\
\hline
\end{tabular}


Vol. 7 (1998): 409-422.

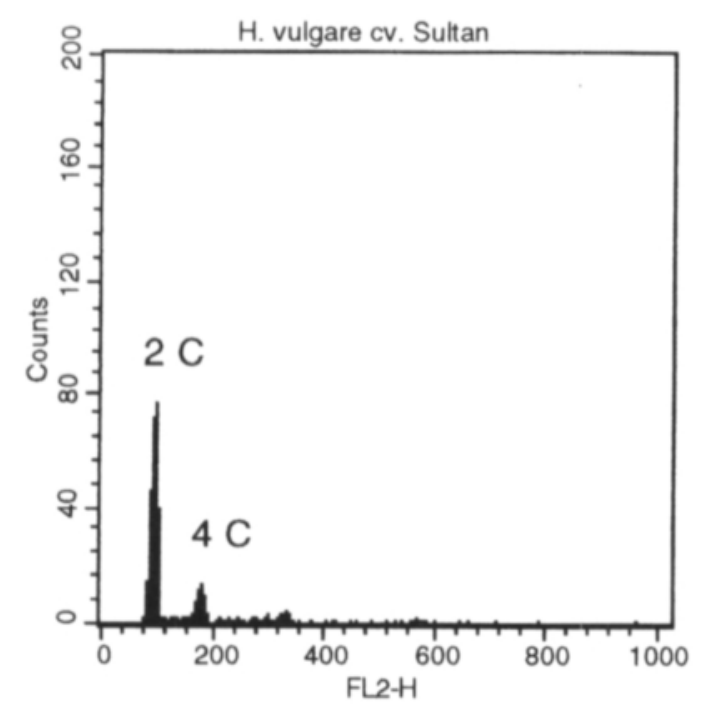

a.

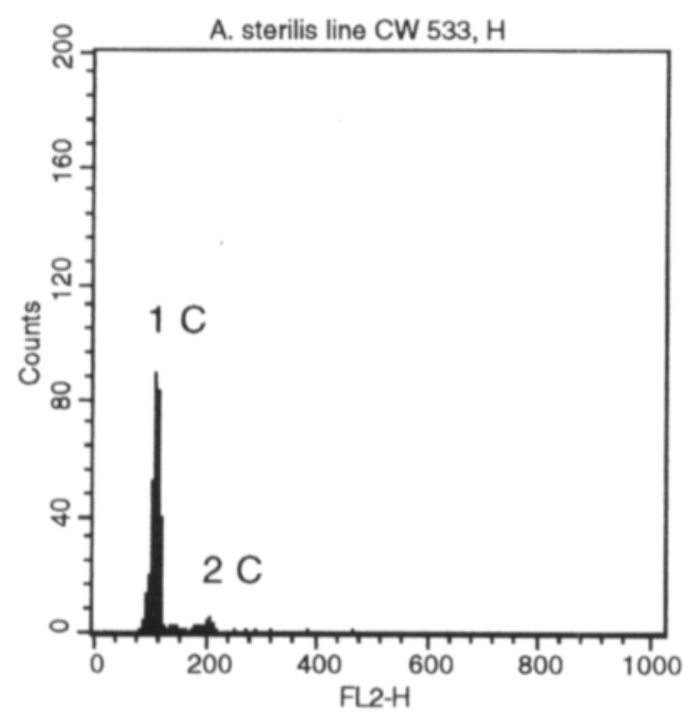

C.

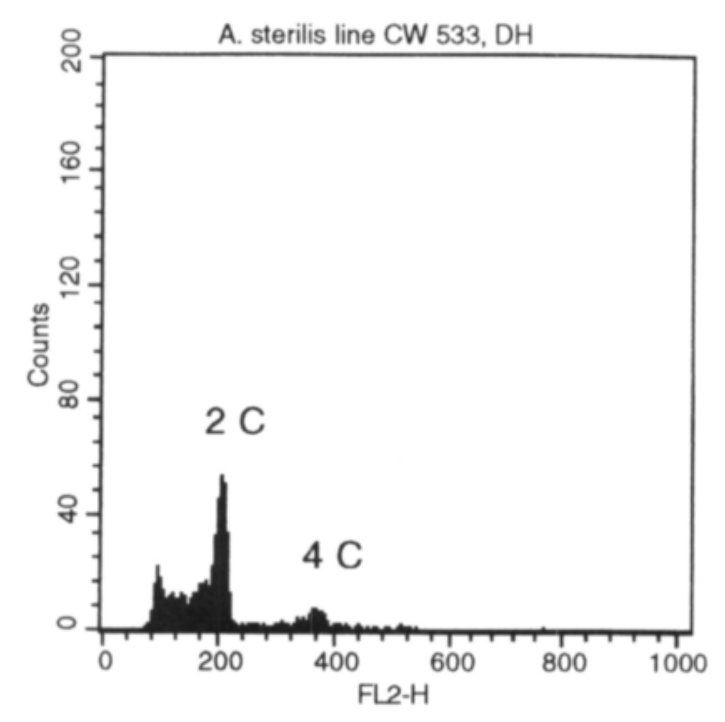

b.

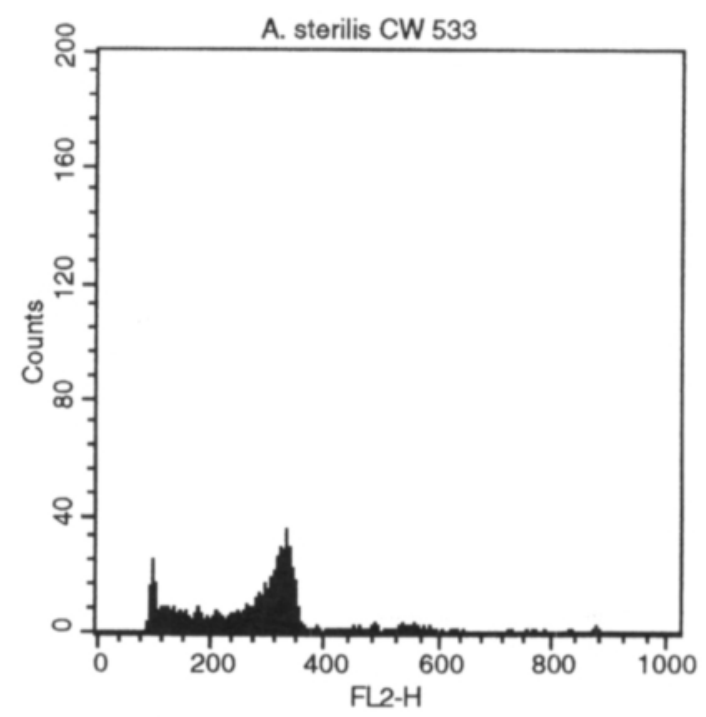

d.

Fig. 2. Flow cytometer analysis of DNA content of regenerated plants, 2C indicating normal diploid (eg. hexaploid in Avena sterilis) ploidy level and $4 \mathrm{C}$ doubled genome just prior to cell division. a) Control Hordeum vulgare, cv. Sultan, b) Diploid $(2 \mathrm{n}=6 \mathrm{x}=42)$ A. sterilis regenerant line CW 533, c) Haploid $(\mathrm{n}=3 \mathrm{x}=21)$ A. sterilis regenerant line CW 533, d) A. sterilis regenerant line CW 533 with DNA content over 6x ploidy level. 


\section{AGRICULTURAL AND FOOD SCIENCE IN FINLAND}

Kiviharju, E. et al. The effect of genotype on anther culture of oats

\section{Discussion}

In line with the report of Rines (1983) on A. sati$v a$, a strong genotype effect was demonstrated for anther culture response of oat, as well as for naked oat and $A$. sterilis. Although cultivated oat is recalcitrant in anther culture, callus induction rates obtained in our experiments [16\% (7/44) of genotypes demonstrated over 5\% induction] were at the same level as Han-Min et al. (1990) reported for winter wheat [17\% (37/215) of genotypes exceeded $5 \%$ induction], but lower than that reported by Orlov et al. (1993) for common wheat $[43 \%(13 / 30)$ of tested genotypes exceeded $4 \%$ response level]. Of 100 oat genotypes, two cultivars, Stout and 'Clintford' were reported to exceed $6 \%$ callus induction and produce callus consistently (Rines and McCoy 1980, Rines 1983, Rines et al. 1992). Under optimal conditions, $30 \%$ of anthers of these cultivars were reported to produce calli. In our experiments, cv. Stout had a high induction rate $(10.5 \%$ on hormone-free medium; $5.0 \%$ on 2,4-D-medium). In addition to Stout, six other genotypes of the 44 tested, exceeded $6 \%$ callus initiation frequency. Thirty two percent (14/44) of genotypes showed no response in our experiments, which is considerable, but still less than for maize, where Hongchang et al. (1991) reported that nearly half of the genotypes failed to develop calli or embryos $(13 / 25 ; 13 / 30)$.

Sixteen percent $(7 / 44)$ of the oat genotypes produced embryo structures, of which only $4,5 \%$ (2/44) produced them consistently. Another genotype capable of consistent, and even better embryo production efficiency than Stout, was WW 18019, despite its low overall response. In contrast to oat, all of the six naked oat genotypes tested produced embryo structures, one of them (Bor 1306) in very high numbers (up to 169.2 embryos/100 anthers). However, no plant regeneration was achieved from embryo structures of oat, naked oat or A. sativa x A. sativa crosses. Contrary to wheat, where hybrid vigour has been strongly expressed in anther culture competence (Hu Han 1986, Ekiz and Konzak 1991, Pauk et al. 1991), heterozygosity did not lead to better anther culture performance in our study on cultivated oat.

Correlation between the level of embryo production and plant regeneration was reported to be very low (Foroughi-Wehr et al. 1982, Deaton et al. 1987), and these two phenomena seem to be genetically unrelated (Knudsen et al. 1989, Larsen et al. 1991). Examples can be found from triticale (Balatero et al. 1995), barley (Larsen et al. 1991, Logue et al. 1993), wheat (Orlov et al. 1993) and rice (Chaleff and Stolarz 1981, Mandal and Gupta 1995). In our study on cultivated oat, plants were not regenerated, although embryo production was quite high is some genotypes.

Immature embryo cultures of A. sterilis genotypes were reported to have lower regeneration frequencies compared with oat and naked oat (Rines and McCoy 1981). However, according to the results of our experiments, anther culture characteristics of wild oat are better than those of cultivated oat. Eighty seven percent (13/15) of the A. sterilis lines tested produced embryo structures, of which three genotypes produced 25 or more transferrable embryos/100 anthers. Embryo induction rates were also markedly higher in tested wild oat genotypes than in A. sativa $\mathrm{x}$ A. sterilis crosses. Naked oat performed better than oat and the means of embryo induction rates of naked oat and wild oat were about the same in the most responsive induction medium containing 2,4-D.

Plant regeneration was achieved from four wild oat lines and this regeneration capacity was also inherited in the A. sativa $\mathrm{x}$ A. sterilis cross Puhti x CAV 2648: three green and two albino plants were produced in anther culture. Wild species have been reported to respond better than cultivated species in other crops including potato, Solanum tuberosum L., (Rokka et al. 1996, Veilleux 1996). Crosses between cultivated and wild rye (Secale cereale x Secale vavilovii L.) were also shown to respond better than cultivated rye genotypes (Rakoczy-Trojanowska et al. 1997). In contrast, wild wheat species (Orlov et al. 1993) were reported to be weaker in response 


\section{AGRICULTURAL AND FOOD SCIENCE IN FINLAND}

Vol. 7 (1998): 409-422.

in anther culture than common wheats. Successful production of plants from the Avena sativa $\mathrm{x}$ Avena sterilis cross opens up also the possibility for transferring anther culture ability from wild oat to breeding material of cultivated oat through a crossing program. At least within species, Balatero et al. (1995) suggested, that high embryo induction and green plant regeneration can easily be transferred and fixed in non-responsive or low-responsive lines through breeding and selection. Hou et al. (1994) also found selection of recombinant genotypes for higher green plant regeneration ability effective and considered improvement of anther culture response possible by crossing and selection.

In two wild oat genotypes (CW 533, 16), producing the highest numbers of green plants, approximately two thirds of the plants initiated on medium containing 2,4-D were haploid (64$65 \%)$ and one third diploid (24-36\%). CW 533 produced three $(8 \%)$ plants with DNA content close to higher ploidy levels $(2 \mathrm{n}=9 \mathrm{x}$ or $12 \mathrm{x})$ according to flow cytometry analysis. Seed set of these plants was disturbed, but some seeds did develop in each panicle. These results are in agreement with those of Masojc et al. (1993), who in wheat anther culture obtained plants of which $45 \%$ were haploids, $29 \%$ spontaneous diploids and $26 \%$ had abnormal chromosome numbers. In our experiments, the ratio of haploid to diploid regenerants varied with regard to genotype and medium used. Two low responding genotypes (CAV 1191, CAV 2941) produced only haploids. The A. sativa $\times$ A. sterilis cross produced one haploid and one diploid plant (one died). In barley as many as $80 \%$ of the anther culture regenerants were reported to be doubled haploids (Gudu et al. 1993).

In general, callus induction and embryo production of oat was better on hormone-free medium than in the presence of auxin, confirming the reported auxin inhibition of oat anther cul- ture (Rines 1983). In contrast, naked oat and wild oat genotypes were not sensitive to 2,4-D. In fact, the best embryo induction and plant regeneration results were obtained using induction medium containing 2,4-D (only one wild oat genotype produced mature plants originating from hormone-free medium). Moreover, anthers of progeny from both $A$. sativa $\times$ A. sterilis crosses produced more embryos on medium containing 2,4-D, although plants did regenerate from embryos from both induction media. Two albino plants from the intraspecific cross, and almost all of the albinos regenerated from wild oat material, were initiated on induction medium containing auxin, indicating a possible albino production enhacing effect of 2,4-D. Nevertheless, three oat genotypes produced a few calli only on medium with $2,4-\mathrm{D}$, indicating the complex hormonal regulation of oat anther culture. Further investigations are needed, since although auxin inhibition seems clear, Rines (1983) reported regeneration of three anther-derived $A$. sativa plants from anther cultures initiated on medium containing 2,4-D.

Maltose was a better carbohydrate source than sucrose, as embryo production in WW 18019 was about six times higher on maltose than on sucrose medium. Cultivar Stout produced embryos in this experiment only on maltose medium, although embryo induction also occurred on a medium containing sucrose.

Acknowledgements. The authors wish to thank Ms. Sirpa Moisander for excellent technical assistance, M.Sc. VeliMatti Rokka and M.Sc. Airi Tauriainen for expertise in flow cytometry analysis and Dr. Jonathan Robinson for his editorial assistance. Most of the genotypes of cultivated oats were kindly provided by Boreal Plant Breeding, Finland, cv. Stout by Prof. Rines from University of Minnesota, USA and line WW 18019 by Svalöf Weibull, Sweden. A. sterilis lines were kindly provided by the USDA National Small Grains Collection, Aberdeen, Idaho, USA. This work was supported by the Finnish Ministry of Agriculture and Forestry. 


\title{
AGRICULTURAL AND FOOD SCIENCE IN FINLAND
}

\author{
Kiviharju, E. et al. The effect of genotype on anther culture of oats
}

\section{References}

Balatero, C.H., Darvey, N.L. \& Luckett, D.J. 1995. Genetic analysis of anther-culture response in $6 x$ triticale. Theoretical and Applied Genetics 90: 279-284.

Bennett, M.D., Smith, J.B. \& Heslop-Harrison, J.S. 1982. Nuclear DNA amounts in angiosperms. Philosophical Transactions of the Royal Society of London, Series B, 216: 179-199.

Bullock, W.P., Baenziger, P.S., Schaeffer, G.W. \& Bottino, P.J. 1982. Anther culture of wheat (Triticum aestivum L.) F,'s and their reciprocal crosses. Theoretical and Applied Genetics 62: 69-74.

Chaleff, R.S. \& Stolarz, A. 1981. Factors influencing the frequency of callus formation among cultured rice (Oryza sativa) anthers. Physiologia Plantarum 51: 201-206.

Chung, S.W. 1980. Anther culture in oats (Avena sativa L.). Ph.D. Thesis. McGill University, Montreal. Dissertation Abstracts 41: 2845-B.

Croughan, T.P., McKenzie, K.S. \& Pizzolatto, M.M. 1985. The use of anther culture to expedite the breeding and release of a new variety of rice. Annual Progress Report, Louisiana, Agricultural Experimental Station, No. 77: 64-65.

Deaton, W.R., Metz, S.G., Armstrong, T.A. \& Mascia, P.N. 1987. Genetic analysis of the anther-culture response of three spring wheat crosses. Theoretical and Applied Genetics 24: 334-338.

De Buyser, J., Henry, Y., Lonnet, P., Herzog, R. \& Hespel, A. 1987. 'Florin': A doubled haploid wheat variety developed by the anther culture method. Plant Breeding 98: 53-56.

Dunwell, J.M. 1985. Anther and ovary culture. In: Bright, S.W.J. \& Jones, M.K.G. (eds.). Cereal Tissue and Cell Culture. Dordrecht: Martinus Nijhoft/Dr W. Junk Publishers. p. 1-44.

Ekiz, H. \& Konzak, C.F. 1991. Nuclear and cytoplasmic control of anther culture response in wheat: III. Common wheat crosses. Crop Science 31: 1432-1436.

Foroughi-Wehr, B., Friedt, W. \& Wenzel, G. 1982. On the genetic improvement of androgenetic haploid formation in Hordeum vulgare L. Theoretical and Applied Genetics 62: 233-239.

Gana, A.J., Sharma, G.C., Zipf, A., Saha, S., Roberts, J. \& Wesenberg, D.M. 1995. Genotype effect on plant regeneration in callus and suspension cultures of Avena. Plant Cell, Tissue and Organ Culture 40: 217224.

Ghaemi, M. \& Sarrafi, A. 1994. The effect of the "D" genome from synthetic wheat lines in anther culture responses. Plant Breeding 112: 76-79.

Gudu, S., Procunier, J.D., Ziauddin, A. \& Kasha, K.J. 1993. Anther culture derived homozygous lines in Hordeum bulbosum. Plant Breeding 110: 109-115.

Han-Min, Y., Keppenne, V.D., Baenziger, P.S., Berge, T. \& Liang, G.H. 1990. Effect of genotype and medium on wheat (Triticum aestivum L.) anther culture. Plant Cell, Tissue and Organ Culture 21: 253-258.

Ho, K.M. \& Jones, G.E. 1980. Mingo barley. Canadian Journal of Plant Science 60: 279-280.
Hoffmann, B., Schumann, G. \& Krũger, H.-U. 1991. In vitro androgenesis in wheat (Triticum aestivum L. ) I. Effect of donor plant genotype on the development of pollen derived macrostructures and plantlets. Archiv für Züchtungsforschung 21 (2): 153-159.

Hongchang, M., Liang, G.H. \& Wassom, C.E. 1991. Effects of growth regulators and genotype on callus and embryoid induction from maize anther culture. Plant Breeding 106: 47-52.

Hou, L., Ullrich, S.E. \& Kleinhofs, A. 1994. Inheritance of anther culture traits in barley. Crop Science 34: 12431247.

Hu, D.F., Yuan, J.Y., Tang, Y.L. \& Liu, J.P. 1986. Jinghua No. 1: a winter wheat variety derived from pollen sporophyte. Scientia Sinica Serie B 29: 733-745.

$\mathrm{Hu}, \mathrm{H} .1986$. Wheat: improvement through anther culture. In: Bajaj, Y.P.S. (ed.). Biotechnology in agriculture and forestry, vol. 2. Berlin, Heidelberg: Springer-Verlag. p. 56.

Jones, A.M. \& Petolino, J.F. 1987. Effect of donor plant genotype and growth environment on anther culture of soft red winter wheat (T. Aestivum L.). Plant Cell, Tissue and Organ Culture 8: 215-223.

Kiviharju, E., Puolimatka, M. \& Pehu, E. 1997. Regeneration of anther-derived plants of Avena sterilis. Plant Cell, Tissue and Organ Culture 48: 147-152.

Knudsen, S., Due, I.K. \& Andersen, S.B. 1989. Components of response in barley anther culture. Plant Breeding 103: 241-246.

Kuhlmann, U. \& Foroughi-Wehr, B. 1989. Production of doubled haploid lines in frequencies sufficient for barley breeding programs. Plant Cell Report 8: 7881.

Larsen, E.T., Tuvesson, I.K.D. \& Andersen, S.B. 1991. Nuclear genes affecting percentage of green plants in barley (Hordeum vulgare L.) anther culture. Theoretical and Applied Genetics 82: 417-420.

Lazar, M.D., Baenziger, P.S. \& Schaeffer, G.W. 1984. Combining abilities and heritability of callus formation and plantlet regeneration in wheat (Triticum aestivum L.) anther cultures. Theoretical and Applied Genetics 68: 131-134

- , Schaeffer, G.W. \& Baenziger, P.S. 1990. The effects of interactions of culture environment with genotype on wheat (Triticum aestivum) anther culture response. Plant Cell Reports 8: 525-529.

Logue, S.J., Giles, L.C. \& Sparrow, D.H.B. 1993. Genotype and environment strongly influence barley anther culture response using Australian genotypes. Australian Journal of Botany 41: 227-236.

Lu, C.S., Sharma, H.C. \& Ohm, H.W. 1991. Wheat anther culture: effect of genotype and environmental conditions. Plant Cell, Tissue and Organ Culture 24: 233-236.

Mandal, N. \& Gupta, S. 1995. Effect of genotype and culture medium on androgenetic callus formation and green plant regeneration in indica rice. Indian Journal of Experimental Biology 33: 761-765.

Masojc, P., Lukow, O.M., Mckenzie, R.I.H. \& Howes, N.K. 


\section{AGRICULTURAL AND FOOD SCIENCE IN FINLAND}

Vol. 7 (1998): 409-422.

1993. Responsiveness to anther culture in cultivars and $F_{1}$ crosses of spring wheat. Canadian Journal of Plant Science 73: 777-783.

Michaelson, M.J., Price, H.J., Ellison, J.R. \& Johnston, J.S. 1991. Comparison of plant DNA contents determined by Feulgen microspectrophotometry and laser flow cytometry. American Journal of Botany 78: 183-188.

Murashige, T. \& Skoog, F. 1962. A revised medium for rapid growth and bioassays with tobacco tissue cultures. Physiologia Plantarum 15: 473-497.

Orlov, P.A., Mavrishcheva, E.B. \& Palilova, A.N. 1993. Estimation of the response to anther culturing in 60 genotypes of different wheat species. Plant Breeding 111: 339-342.

Pauk, J., Kertesz, Z., Beke, B., Bona, L., Csősz, M. \& Matuz, J. 1995. New winter wheat variety:'GK Délibáb' developed via combining conventional breeding and in vitro androgenesis. Cereal Research Communication 23: 251-256.

- , Manninen, O., Mattila, I., Salo, Y. \& Pulli, S. 1991. Androgenesis in hexaploid spring wheat $F_{2}$ populations and their parents using a multiple-step regeneration system. Plant Breeding 107: 18-27.

Petolino, J.F. \& Thompson, S.A. 1987. Genetic analysis of anther culture response in maize. Theoretical and Applied Genetics 74: 284-286.

Polsoni, L. 1991. The induction of microspore embryogenesis in anther culture of oats (Avena sativa L.). M.S. Thesis, University of Guelph, Canada. 126 p.

Rakoczy-Trojanowska, M., Miech, M. \& Malepszy, S. 1997. The influence of genotype and medium on rye (Secale cereale L.) anther culture. Plant Cell, Tissue and Organ Culture 48: 15-21.

Rines, H.W. 1983. Oat anther culture: Genotype effect on callus initiation and the production of a haploid plant. Crop Science 23: 268-272.

- \& McCoy, T.J. 1980. Effect of genotype on initiation of tissue cultures from embryos and anthers of oats (Avena spp.). Agronomy Abstracts. American Society of Agronomy, Madison, Wisconsin. p. 67.

- \& McCoy, T. J. 1981. Tissue culture initiation and plant regeneration in hexaploid species of oats. Crop Science 21: 837-842.

-, Phillips, R.L. \& Somers, D.A. 1992. Application of tissue culture to oat improvement. In: Oat Science and Technology ( Agronomy Monograph no. 33, American Society of Agronomy and Crop Science Society of America, USA. p. 777-791.

- , Riera-Lizarazu, O., Nunez, V.M., Davis, D.W. \& Phillips, R.L. 1997. Oat haploids from anther culture and from wide hybridizations. In: Jain, S.M. et al. (eds.). In vitro haploid production in higher plants. Vol. 4. Netherlands: Kluwer Academic Publishers. p. 205221.

Rokka, V.-M., Pietilä, L. \& Pehu, E. 1996. Enhanced production of dihaploid lines via anther culture of tetraploid potato (Solanum tuberosum L. ssp. tuberosum) clones. American Potato Journal 73: 1-11.

Sun, C.S., Lu, T.-G. \& Söndahl, M.R. 1991. Anther culture of naked oat and the establishment of its haploid suspension cell. Acta Botanica Sinica 33: 417420.

Tuvesson, I.K.D., Pedersen, S. \& Andersen, S.B. 1989. Nuclear genes affecting albinism in wheat (Triticum aestivum L.) anther culture. Theoretical and Applied Genetics 78: 879-883.

Veilleux, R.E. 1996. Haploidy in important crop plants ( potato. In: Jain, S.M. et al. (eds.). In vitro haploid production in higher plants. Vol. 3. Netherlands: Kluwer Academic Publishers. p. 37-49. 


\title{
AGRICULTURAL AND FOOD SCIENCE IN FINLAND
}

Kiviharju, E. et al. The effect of genotype on anther culture of oats

\section{SELOSTUS}

\section{Genotyypin vaikutus kauran, kuorettoman kauran ja villikauran ponsiviljelyvasteeseen}

\author{
Elina Kiviharju, Matti Puolimatka, Marketta Saastamoinen, Simo Hovinen ja Eija Pehu \\ Maatalouden tutkimuskeskus, Boreal Suomen Kasvinjalostus ja Helsingin yliopisto
}

Tutkimuksessa selvitettiin genotyypin vaikutusta kuorellisen ja kuorettoman kauran (Avena sativa L.) ja villikauran (A. sterilis L.) ponsiviljelyvasteeseen auksiinia sisältävällä ja hormonittomalla kasvatusalustalla. Kauran 44 :stä testatusta genotyypistä $70 \%$ tuotti induktioalustalla kallusta tai alkiorakenteita. Kuorettomalla kauralla kaikki testatut kuusi genotyyppiä tuottivat alkiorakenteita. Alkionkehitys kuitenkin pysähtyi eikä taimia erilaistunut kauran tai kuorettoman kauran ponsiviljelmistä. Villikauralla kolme genotyyppiä viidestätoista testatusta regeneroi vihreitä kasveja ponsiviljelyssä. Näistä paras linja, CW 533, tuotti 41 vihreää tainta 600 viljeltyä heteen pontta kohti. Villikauran taimien erilaistumiskyky periytyi villikaura x kaura -risteytysjälkeläisiin. Kauragenotyyppien ponsiviljelyvaste oli parempi hormonittomalla kuin auksiinia sisältävällä alustalla. Sen sijaan kuoreton kaura, villikaura ja risteytykset tuottivat paremman ponsiviljelytuloksen auksiinia sisältävällä kasvatusalustalla. Tulokset vahvistavat genotyypin vaikutuksen kauran ponsiviljelyssä ja identifioivat toimivia A. sterilis genotyyppejä sekä lupaavia viljellyn kauran genotyyppejä jatkotutkimuksiin. 